\title{
TERITORIALITAS RUANG PADA PERMUKIMAN KAMPUNG MELAYU KOTA MAKASSAR
}

\author{
Andi Annisa Amalia; Citra Amalia Amal, \\ Program Studi Arsitektur Universitas Muhammadiyah Makassar \\ Email : annisa@unismuh.ac.id
}

\begin{abstract}
ABSTRAK
Pemanfaatan ruang permukiman di Kampung Melayu Kota Makassar khususnya pada hunian dengan tingkat kepadatan tinggi, secara tidak sadar mengarahkan penghuni mensetting ruang luar sebagai area yang dimilikinya (teritori). Latar belakang utama pembentuk teritori tersebut diantaranya legalitas, lama menghuni, aktivitas dan persepsi. Penelitian ini bertujuan untuk mengetahui batas teritori yang diterapkan dan karakteristiknya pada Kampung Melayu Kota Makassar. Metode penelitian yang digunakan adalah rasionalistik. hasil penelitian membahas batas teritori fisik dan non fisik. Sedangkan karakteristik teritorialitas ruang adalah berbentuk persegi (square), memanjang (linear), berdasarkan waktu, aktivitas, dan latar belakang budaya masyarakat.
\end{abstract}

Kata Kunci : Permukiman, Teritorialitas, Batas, Fisik, Karakteristik

\section{PENDAHULUAN}

Perkembangan penduduk di perkotaan ditandai dengan meningkatnya jumlah penduduk, kepadatan bangunan, jumlah kendaraan dan pemekaran wilayah kota ke arah pinggir kota. Pertumbuhan jumlah penduduk dari waktu ke waktu selain karena faktor alami kelahiran, juga disebabkan karena tingginya urbanisasi. Jumlah penduduk yang semakin meningkat ini tidak seimbang secara sosial member dampak pada kepadatan (density) atau kesesakan (crowded) yang dapat menggerogoti kesejahteraan hidup warga perkotaan.

Dampak pertambahan penduduk tersebut juga dialami di Kota Makassar. Sebagai salah satu kota besar di Indonesia, tahun 2016 jumlah penduduk mencapai angka 1.469.601 Jiwa (Makassar dalam Angka, 2017). Selain itu tahun pada bulan desember tahun 2016 Makassar yang awalnya berjumlah 143 kelurahan saat ini mengalami pemekaran menjadi 153 kelurahan.Hai ini menunjukkan bahwa pertumbuhan penduduk sangat berkaitan erat dengan masalah keruangan pada lokasi permukiman.

Pemanfaatan ruang di kawasan permukiman Kota Makassar khususnya pada hunian dengan tingkat kepadatan tinggi menjadi sangat terbatas dengan aktivitas yang dilakukan penghuninya. Karena kepadatan manusia dan bangunan, penghuni secara tidak sadar telah mensetting ruang luar sebagai area yang dimilikinya (teritori) karena padatnya persil lahan yang mereka miliki, sementara jumlah penghuni dan aktivitas bertambah.

Kampung Melayu adalah salah satu kampung kota yang memiliki kontribusi dalam perkembangan perkotaan di Makassar. Berdasarkan sejarah, kampung ini menandai terbentuknya kawasan kota lama dan kejayaan Makassar tempo dulu sebagai kawasan perdagangan nusantara dan sejarah perjuangan Kerajaan Gowa Tallo.

Fenomena menarik dari penelitian ini adalah munculnya gejala-gejala individualiasme pada permukiman modern ditengah masyarakat kampung yang masih menjunjung tinggi kebersamaan. Organisasi sosial masyarakat lebih mempengaruhi organisasi spatial. Organisasi sosial atau struktur masyarakat penghuni kampung Melayu akan mempengaruhi tata ruang yang dimanfaatkan untuk berbagai aktivitas. Hal ini menjadi salah satu faktor pembentuk teritorialitas ruang dan diterapkan pada permukiman Kampung Melayu.

Teritori disini ditinjau dari orientasi dan batas. Orientasi kampung sangat bergantung pada jalur sirkulasi dengan tidak adanya open space ataupun landmark sebagai figur yang dapat mengarahkan pola perletakkan massa. Orientasi yang terjadicenderung ke arah garis linier yang dijadikan tanda berupa jalan.

Pada tingkat ruang mikro, orientasi membentuk ruang transisi dan pagar pembatas. Ruang transisi dan pagar pembatas merupakan elemen pembentuk teritori. Fenomena terciptanya ruang komunal pada ruang jalan salah satunya diakibatkan 
tidakadanya pembatas fisik. Selain itu faktor sosial masyarakat yang berkonsep kekeluargaan juga menginginkan banyaknya ruang bersama, sehingga kurangnya kontrol akan hal ini. Kemudian mayoritas penghuni beranggapan bahwa ruang luar persil merupakan bagian dari kavling tanah miliknya. Akibatnya para penghuni merasa memiliki hak penuh dalam menggunakan dan menata ruang persil sesukanya. Ruang komunal pun terbentuk baik pada ruang transisi, ruang jalan ataupun tempat lainnya yang dapat menampungkegiatan bersama.

Teritorialitas merupakan perilaku yang berhubungan dengan rasa kepemilikan seseorang terhadap suatu ruang tertentu yang jika dimasuki tanpa izin maka akan menimbulkan ketersinggungan (Laurens, 2004). Ananto Sofian (2015) memaparkan bahwa penghadiran teritorialitas pada permukiman vertikal dapat menjadi salah satu cara untuk menghilangkan keterasingan masyarakat penghuni permukiman horizontal terhadap budaya berhuni di permukiman vertikal.

Halim (2006) menyatakan bahwa teritorialitas merupakan perilaku dimana seseorang ingin menjadi diri sendiri atau menyatakan diri bahwa ia memiliki dan melakukan pertahanan terhadap suatu area. Febrianto, Santoso dan Wulandari (2017) menyatakan bahwa konsep pola spasial teritori hunian masyarakat desa pertanian terdiri atas dua kategori utama yaitu spasial yang terdiri dari tema-tema empiris (pola hunian dan pola lansekap pertanian) dan nilai spasial terdiri dari tema-tema sosial (civitas, aktivitas dan artefak).

Terdapat tiga aspek pembentuk teritorialitas yaitu legalitas, aktivitas dan persepsi yang dapat mempengaruhi maupun mendorong penghuni untuk melakukan ekspansi teriroialitas tersebut. legalitas yang dimaksud adalah adanya bukti hukum kepemilikan atau bukti hak penggunaan atas suatu tempat. aspek aktivitas adalah interaksi sosial masyarakat yang terjadi pada suatu lokasi tertentu. sedangkan aspek persepsi adalah nilai yang berasal dari pemahaman pengguna atau masyarakat mengenai batasan teritorialitas itu sendiri (Widjaja, 2007).

Menurut Tamiya, Dewi R, Sofian dan Adib (2015) menyatakan bahwa pola ekspansi pembentuk teritorialitas perumahan antara lain aspek legalitas, aspek aktivitas dan aktivitas persepsi. Pola ekspansi yang terjadi pada perumahan terbentuk dari lima jenis aktivitas jual beli, berbincang, bermain, menjemur dan memarkir. dari kelima aktivitas ini menghasilkan tiga pola umum ekspansi teritorial, yang pertama pola ekspansi di batas legal, di luar batas legal dan di koridor sebagai teritori publik.

Menurut Burhanuddin (2010), kompleksnya permasalahan yang ada pada ruang publik utamanya di permukiman padat penduduk, dimana ruang tersebut dimanfaatkan oleh masyarakat untuk berinteraksi, ketika ruang yang digunakan untuk kepentingan pribadi seperti halnya menjemur, parkir gerobak dan kendaraan, pilihan lokasinya adalah yang terdekat dengan tempat tinggal, sehingga hal ini tampaknya membentuk suatu teritori ruang pribadi dan ruang bersama.

\section{METODE}

Penelitian yang digunakan adalah penelitian rasionalistik. dimana pendekatan yang digunakan melihat kebenaran bukan semata-mata dari empiri tetapi juga wawacara sebagai suatu bagian konstruksi berpikir. tujuan penelitian ini adalah mengeksplorasi teritorialitas ruang permukiman kampung Melayu dari aspek bentuk dan karakteristiknya berdasarkan objek pengamatan di lapangan. untuk memudahkan penelitian di lapangan maka diperlukan indikator dan objek pengamatan yang diccantumkan pada tabel 1 berikut.

Tabel 1. Indikator dan Objek Pengamatan

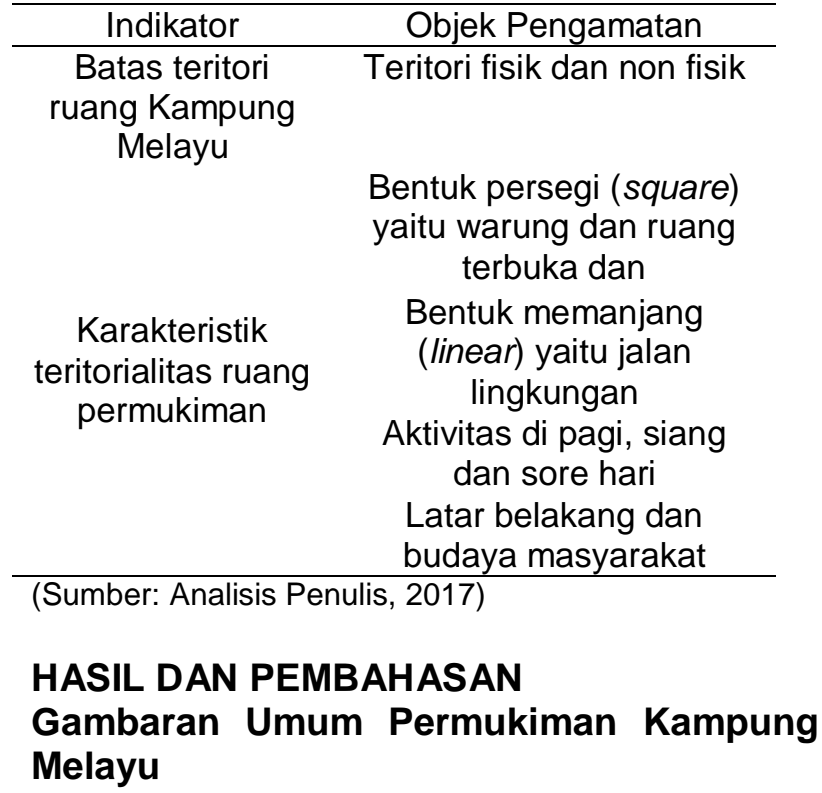


Kelurahan Melayu adalah salah satu dari 9 kelurahan yang berada di Kecamatan Wajo (Kawasan Perkotaan Makassar), dengan kondisi topografi yang relatif datar hingga berbukit.Secara geografis Kelurahan Melayu terletak antara -5,124712 Lintang Selatan dan 119,415594 Bujur Timur dengan batas administrasi sebelah timur berbatasan dengan Kelurahan Bontoala Parang, sebelah barat berbatasan dengan Kelurahan Butung, sebelah utara berbatasan dengan Kelurahan Malimongan Tua, sebelah selatan berbatasan dengan Kelurahan Ende. Pola pemanfaatan lahan di Kampung Melayu didominasi oleh permukiman dan perdagangan dan jasa.

Penduduk Kelurahan Melayu tahun 2017 tercatat sebanyak 4.605 jiwa yang terdiri dari 2014 jiwa penduduk laki-laki dan 2591 jiwa penduduk perempuan. Penyebaran penduduk Kelurahan Melayu yang dirinci menurut RW menunjukkan bahwa penduduk masih terkonsentrasi di wilayah RW 8 yaitu sebanyak 770 jiwa atau sekitar dari total penduduk, disusul RW 2 sebanyak 745 jiwa disusul RW 5 sebanyak 616 jiwa dissusul RW 7 sebanyak 614 jiwa disusul RW 1 sebanyak 521 disusul RW 6 sebanyak 519 disusul RW 3 sebanyak 445 Yang terendah adalah di RW 4 sebanyak 375 jiwa.

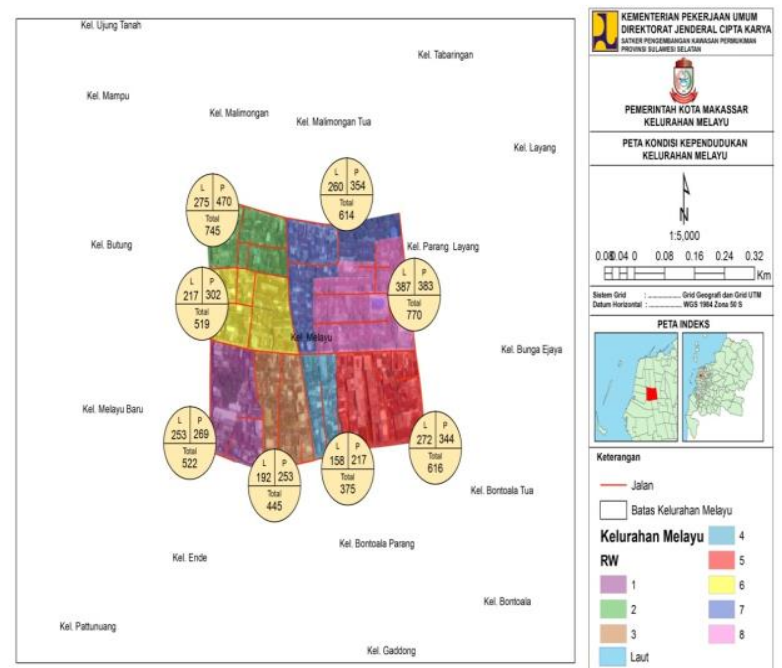

(Sumber: Dokumen RPLP Kelurahan Melayu, 2017, Halaman 8)

Gambar 1. Peta Distribusi Kepadatan Penduduk Kelurahan Melayu

Batas Teritori Ruang

Teritori Ruang Fisik
Batas teritori ruang yang terbentuk pada permukiman Kampung Melayu terbagi menjadi dua yaitu teritori fisik dan non fisik. Teritori fisik sebagai kontrol ruang berupa (1) Penerapan double gate pada fasilitas peribadatan yaitu adanya gerbang di masingmasing akses jalan menuju Masjid Al Fajri yang terletak di Jalan Muhammadiyah Lorong 202 B, (2) Signage komunitas di ujung jalan diantaranya menunjukkan komunitas sepakbola, maupun identitas permukiman sebagai lorong KB (Keluarga Berencana), (3) Akses bangunan hunian berupa jalan berbentuk memanjang dilengkapi pintu besi sebagai penegasan batas persil yang dimiliki penghuni dan pintu utama menuju bangunan, (4) Aturan cul-de-sac (gang buntu) pada beberapa hunian yang berhadapan dengan jalan selebar 1-2 meter sehingga kecendrungan koridor permukiman mengarah ke semi privat, (5) Pagar bangunan hunian bermaterial besi cenderung transparan dan tembok masif, (6) Teras hunian sebagai ruang transisi yang difungsikan sebagai ruang penerimaan tamu temporer maupun ruang berjualan.
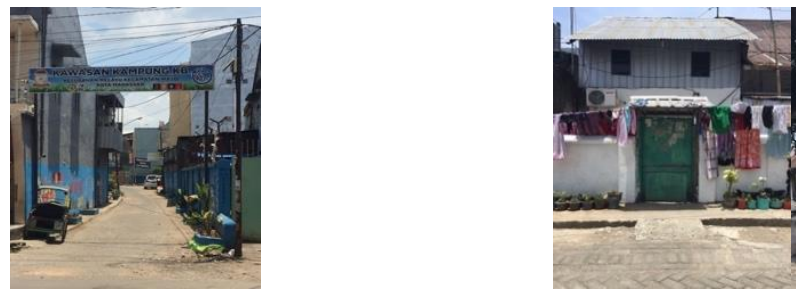

(Sumber: Dokumentasi Penulis, 2017)

Gambar 2. Teritori Fisik Kampung Melayu

\section{Teritori Ruang Non Fisik}

Teritori non fisik pada permukiman Kampung Melayu terbentuk karena kesadaran warga masyarakat akan batas wilayah. umumnya teritori ini dibentuk oleh beberapa komunitas atau kelembagaan masyarakat yang berdomisili di dalam permukiman tersebut yang diwujudkan pada ruang publik dan ruang peralihan.

Ruang publik adalah area terbuka yang disepakati oleh warga dalam penggunaan dan pemeliharaannya bersifat kolektif. contoh gang permukiman maupun sempadan jalan. antara lain Lorong permukiman, area PKL dan parkir. Setting teritorial yang terbentuk berupa (1) Kesepakatan diantaranya lorong 
permukiman memperbolehkan adanya aktivitas bermain anak karena tidak adanya sarana bermain dengan batasan waktu penggunaan, (2) Area PKL berupa pedagang bakso yang berjualan di bahu jalan dan wajib membersihkan area ketika sudah selesai beraktivitas, (3) Parkir diperbolehkan sepanjang jalan yang bukan area masuk bangunan maupun depan toko (area komersil) dengan jangka waktu hanya 1-3 Jam.

Ruang peralihan dibuat sebagai penghubung berbagai teritori yang memiliki perbedaan sifat. Area pintu masuk sekolah misalnya maupun Masjid merupakan daerah transisi. pada area ini, gugatan teritori individual dan kolektif biasanya saling tumpang tindih sehingga perlu ada kesepakatan untuk menghindari terjadinya konflik. Keberhasilan ruang peralihan dalam membentuk ruang komunal di Permukiman Kampung Melayu cukup baik memberikan kontribusi demi kenyamanan lingkungan.

\section{Karakteristik Teritorialitas Ruang Teritorialitas Ruang Berbentuk Persegi (Square)}

Bentuk dan pola permukiman di Kelurahan Melayu pada umumnya terdiri dari dua yakni secara linear mengikuti pola jalan eksisting dan berbentuk cluster, rumah umumnya menyebar dan ada yang berkumpul dalam sebuah titik sehingga secara visual terlihat padat. Bentuk ruang persegi cenderung memusat atau terfokus dalam ruang .

Karakteristik teritorialitas ruang bentuk persegi (square) adalah (1) Ruang terbuka berupa lapangan yang terbentuk secara spontan karena pola ruang hunian disekitarnya mengelilingi lahan kosong tersebut, selain itu terdapat pula beberapa hunian yang memiliki ruang terbuka berbentuk square berupa pekarangan, (2) Warga dapat mengontrol dan mengawasi ke segala sisi 'ruang' interaksi karena bentuk ruang yang persegi sehingga menimbulkan rasa aman dalam beraktivitas, (3) Pembatas ruang (enclosure) lebih jelas karena adanya pagar hunian di pekarangan rumah warga ataupun menggunakan material dan elevasi
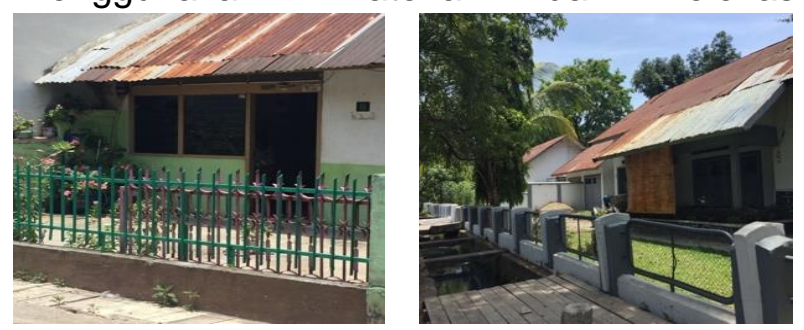

permukaan yang berbeda.

(Sumber: Dokumentasi Penulis, 2017)

Gambar 3. Pekarangan Rumah di Kampung Melayu

\section{Teritorialitas Ruang Berbentuk Memanjang (Linear)}

Bentuk ruang memanjang (linier) aktivitasnya cenderung memancar atau menyebar sepanjang pola liner yang ada dengan memanfaatkan jalan sebagai ruang beraktivitas/interaksi. Oleh karena keterbatasan lahan, maka sebagian warga menggunakan jalan untuk melakukan aktivitas/interaksi. Pengamatan dilakukan pada dua jenis jalan berdasarkan hirarkinya yaitu (1) Jalan Lokal Sekunder II dengan lebar 3- 5 Meter dan Jalan lingkungan dengan lebar 1-2 meter.

Pada Jalan lokal sekunder dengan melakukan pengamatan di Jalan Muhammadiyah dan Jalan $\mathrm{KH}$ Abdullah didapatkan hasil bahwa (1) Luasan cukup memadai untuk menampung aktivitas warga dan memiliki keterbukaan ruang, dapat digunakan untuk aktivitas yang bersifat aktif serta cukup mendukung jarak dan aspek pandang bagi pengguna ruang (view), (2) Rumah warga yang melingkupi ruang dapat memudahkan akses ke ruang tersebut karena relatif lebih dekat dan mudah, (3) Jalan ini dilalui kendaraan bermotor yang melayani antar antar RW, penghubung antara kelurahan di sekitar permukiman Kampung Melayu dan penghubung ke jalan kolektor.
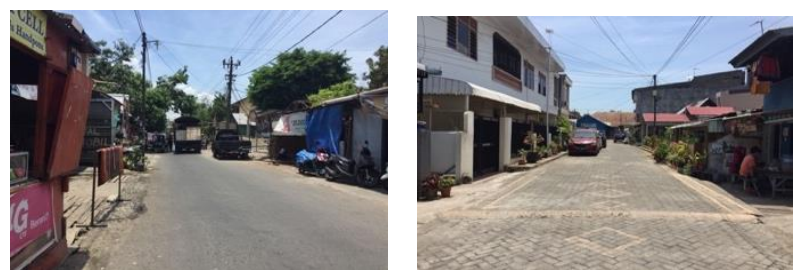

Sumber : Dokumentasi Penulis, 2017

Gambar 4. Jalan Lokal Sekunder II Kampung Melayu

Jalan Lingkungan dengan lebar 1-2 Meter dilakukan pengamatan di Lorong 226, Lorong 202, dan Jalan Muna 43-47 didapatkan hasil bahwa (1) Kesan ruang terasa sempit dan tertutup karena dibatasi oleh rumah warga sehingga tingkat kenyamanan rendah dari aspek view dan aspek gerak dalam 
melakukan aktivitas, (2) Rumah warga saling berhadapan sehingga potensi rasa saling memiliki dan kekerabatan antar warga sekitarnya yang umumnya berada pada tingkat sosial yang hampir sama, (3) Komponen aktivitas ruang yang ada

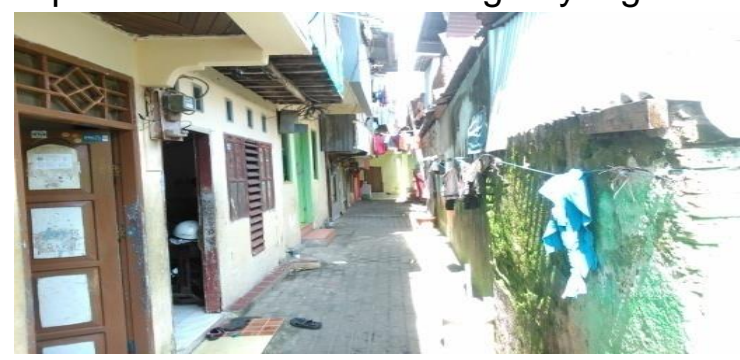

cenderung multifungsi karena beberapa warga mensetting teritorinya dengan memfungsikan teras sebagai ruang berjualan dan jemuran di ruang yang tersisa ataupun di koridor depan rumah tinggalnya.

(Sumber: Dokumentasi Penulis, 2017)

Gambar 5. Jalan Lingkungan Lebar 1 Meter di Kampung Melayu

\section{Karakteristik Teritorialitas Berdasarkan Aktivitas dan Waktu}

Ruang

Selama pengamatan di lapangan ditemui beberapa tempat yang merupakan aktivitas publik berupa kegiatan berkumpul atau bentuk kegiatan interaksi sesama warga baik bertetangga maupun kelompok komunitas yang sama. aktivitas tersebut lebih banyak dilakukan di malam dan sore hari. Hal ini karena pada sore dan malam hari adalah waktu luang bagi seluruh warga, dimana setelah warga melakukan aktivitas sehari-hari, ada yang telah pulang bersekolah, selesai bekerja. disamping itu suhu pada sore hari sudah mulai tidak terlalu panas sehingga lebih nyaman beraktivitas di ruang luar. Perubahan aktivitas di luar ruang berdasarkan waktu cenderung terpusat (berkumpul) pada koridor lorong atau di teras rumah masing-masing (bersama keluarga).

Selain aktivitas yang umum, juga beberapa aktivitas khusus misalnya keagamaan. Proses daur hidup dan menjalani aktivitas di lingkungan binaan melihat dari sisi inhabitasi di Kampung Melayu, memiliki karakteristik khas dimana masih adanya beberapa hunian di ruas jalan tertentu yang dijadikan tempat berkumpul masyarakat sekitar, biasanya mereka yang merupakan saudagar, tokoh masyarakat ataupun orang yang lebih tua. Aktivitas yang dilakukan pada rumah tersebut diantaranya memperingati hari besar islam seperti maulid Nabi Besar Muhammad SAW(maudu'), buka puasa bersama, maupun peringatan 10 Muharram.

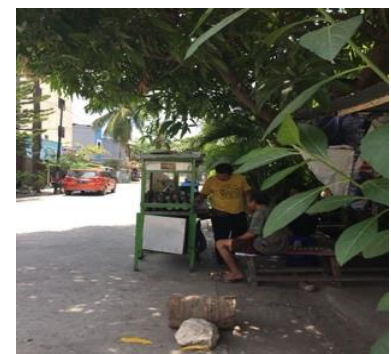

(Sumber: Dokumentasi Penulis, 2017)

Gambar 6. Aktivitas di Koridor Jalan

Aktivitas mingguan yang rutin dilakukan oleh masyarakat Kampung Melayu adalah kerja bakti sebagai bentuk kepedulian mereka terhadap lingkungannnya. Teritorialitas ruang yang terbentuk pada kegiatan ini adalah masyarakat cenderung membersihkan sesuai wilayah teritorialitasnya yaitu batas huniannya, batas administratif tempat mereka tinggal misalnya mereka berkumpul membersihkan dalam satu RT, RW atau bila kegiatannya skala kelurahan akan lebih melibatkan elemen-elemen masyarakat secara struktural maupun dalam satu kelompok komunitas.
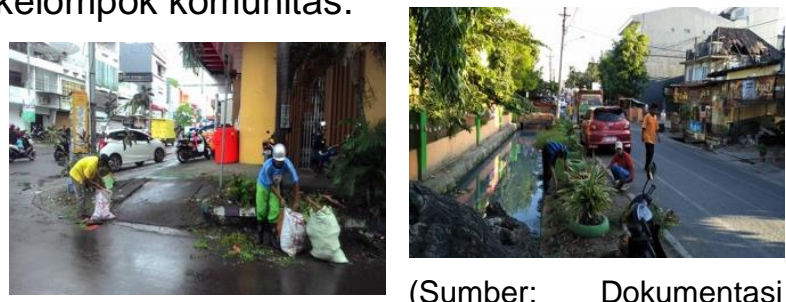

Penulis, 2017)

Gambar 7. Aktivitas Membersihkan Lingkungan di Kampung Melayu

\section{Karakteristik Teritorialitas Ruang Berdasarkan Latar Belakang, Budaya Masyarakat dan Lama Menetap}

Aspek norma, budaya dan psikologis dari masyarakat dapat berpengaruh dalam pembentukan ruang, sehingga latar belakang masyarakat tidak dapat diabaikan begitu saja. masyarakat yang bermukim di lokasi penelitian terdiri dari beragam diantaranya 
suku Bugis Makassar, Suku Ternate dan juga Etnis Tionghoa. keragaman ini menimbulkan toleransi bagi masyarakatnya. walaupun ada aktivitas yang dilakukan berdasarkan kelompok atau komunitas yang sama, tetapi dalam 'ruang' mereka dapat menyatu dan tidak terlihat adanya konflik.

Faktor sosial dan budaya yang mempengaruhi terbentuknya ruang adalah pola aktivitas yang cenderung mengelompok dan terdapatnya tempat berkumpul yang menjadi ciri khas mereka. selain itu terdapat faktor kedekatan budaya atau status sosial yang sama, seperti asal daerah, etnis, agama, pekerjaan dan pendidikan serta kegemaran/hobby dan umur.

Pengaruh lain dari latar belakang masyarakat adalah bentuk rumah yang ditempati. secara umum rata-rata rumah yang mereka tempati masih bergaya arsitektur lokal bahkan masih ada yang mencirikan arsitektur kolonial dan konsep Melayu. Selain itu untuk kepadatan bangunan hunian masih kategori kepadatan sedang. Halaman rumah memiliki luasan yang berbeda bahkan ada yang langsung berbatasan jalan (tanpa halaman). rumah yang masih berkonsep Melayu atau kolonial, rata-rata masih memiliki halaman yang berbentuk memanjang mengikuti lebar atau panjang rumah. Orientasi rumah umumnya menghadap ke jalan sehingga penghuni yang bertetangga atau yang berhadapan dapat sering bertemu.

Aspek karakteristik penghuni Kampung Melayu yang paling berpengaruh terjadinya aktivitas ekspansi teritorialitas pada masyarakat adalah lama menetap. Analisis dilakukan berdasarkan hasil wawancara kepada warga di lokasi penelitian yang dibagi menjadi lima kategori yaitu 81) Lama menetap $<1$ tahun, (2) Lama menetap 1-5 tahun, (3) Lama menetap 6-10 tahun, (4) Lama menetap 11-25 tahun, dan (5) Lama menetap > 25 tahun.

Masyarakat yang (1) Lama menetap $<1$ tahun cenderung melakukan aktivitas berbincang-bincang, (2) Lama menetap 1-5 tahun cenderung melakukan aktivitas memarkirkan kendaraan dan bermain di luar persil mereka, (3) Lama menetap 6-10 tahun cenderung melakukan aktivitas menjemur pakaian, (4) Masyarakat dengan lama menetap 11-25 tahun dan > 25 tahun cenderung melakukan aktivitas berjualan. Sehingga dapat terlihat bahwa masyarakat yang telah menghuni Kampung Melayu $<1$ tahun cenderung melakukan aktivitas ekspansi dengan intensitas paling rendah dan masyarakat yang paling lama tinggal (>25 tahun) cenderung paling sering melakukan aktivitas ekspansi teritorialitas. Hal ini menunjukkan bahwa semakin lama masyarakat tinggal, maka cenderung semakin tinggi jenis aktivitas ekspansi teritorialitas yang dilakukannya serta kontinuitasnya juga lebih tinggi.

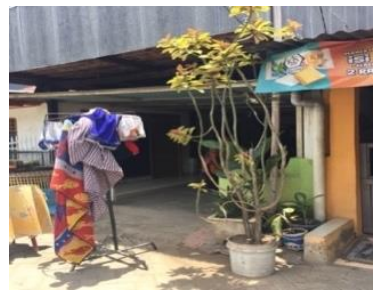

(Sumber: Dokumentasi Penulis, 2017)

Gambar 8. Bentuk Ekspansi Teritorial yang dilakukan Masyarakat Kampung Melayu

\section{Kesimpulan}

Batas teritori permukiman Kampung Melayu yang terbentuk secara fisik dan non fisik merupakan kontrol ruang penghuni terhadap ruang luarnya yang tersetting karena aktivitas, persepsi dan legalitas serta orientasi hunian. Karakteristik teritorialitas ruang memiliki bentuk dan pola berbeda-beda tergantung aktivitas, waktu, latar belakang budaya dan lama menetap masyarakat di Permukiman Kampung Melayu.

\section{DAFTAR PUSTAKA}

Burhanuddin. 2010. Karakteristik Teritorialitas Ruang pada Permukiman Padat di Perkotaan. Jurnal Ruang Jurusan Arsitektur Fakultas Teknik Universitas Tadulako, 2 (1): 40. 
Dewinna Farah Puspita dan Angger Sukma Mahendra. 2017. Teritori Feminisme pada Kantor dan Apartemen. Jurnal Sains dan Seni Pomits, 6 (2):

Halim, D. 2005. Psikologi Arsitektur. Penerbit PT Gramedia Widiasarana Indonesia: Jakarta

Redi S.F., Lisa D.W., Herry S. 2017. Pola Spasial Teritori pada Lanskap Hunian Masyarakat Peladang Desa Juruan Laok Madura Timur. Jurnal Teknik Arsitektur ARTEKS, 2 (1).

Sofian D.A., 2015. Adaptasi Teritorialitas pada Permukiman Horizontal ke dalam Permukiman Vertikal. Jurnal Temu IImiah IPLBI 2015.

Tamiya M., Saada K, Dewi, et.al. 2015. Teritorialitas Masyarakat Perumahan Menengah ke Bawah, Studi Kasus : Perumahan Sukaluyu, Cibeunying Kaler, Bandung. Program Studi Magister Arsitektur, Sekolah Arsitektur, Perencanaan dan Pengembangan Kebijakan, Institut Teknologi Bandung. Prociding Temu IImiah IPLBI 2015, C 096: 6.

Widjaja \& Pele. 2007. Teritorialitas Domestik Rumah pada Dua Kampung di Kota Bandung. Disertasi Program Studi Arsitektur ITB. Bandung: Program Pascar¥sarjana.....

Dokumen Rencana Penataan Lingkungan Permukiman Kelurahan Melayu Kota Makassar. 2017. Program KOTAKU. Direktorat Jenderal Cipta Karya.

Kota Makassar dalam Angka 2017. Penerbit BPS Kota Makassar. 